\title{
WIZERUNEK RODZINY TRANSNARODOWEJ W ŚWIETLE KONCEPCJI PIĘTNA I STYGMATYZACJI
}

\section{WSTĘP}

Sposób funkcjonowania i struktura rodziny są ściśle powiązane z takimi zmianami, jak przekształcenia ustrojowe w kraju pochodzenia, przeobrażenia na rynku pracy, rewolucja informatyczna i technologiczna oraz z wieloma innymi przemianami społeczno-kulturowymi. Obecna sytuacja na rynku pracy, poziom bezrobocia i sytuacja materialna polskich rodzin moga być przyczynami decyzji o migracji zarobkowej osób pełniących role rodziców. Międzynarodowa mobilność zawodowa jednego bądź obojga rodziców sprawia, że życie rodzinne zaczyna być podporządkowane cyklicznym wyjazdom i przyjazdom migranta. Izabela Szczygielska (powołując się na dane z raportu Banku Światowego Migration and Remittances Eastern Europe), wskazuje na to, że w żadnej ze sfer życia migracja nie jest tak odczuwalna, jak w życiu rodzinnym ${ }^{1}$. Poza tym modyfikuje relacje między członkami rodziny, strukturę systemu rodzinnego, wpływa także na pełnione role społeczne, opiekę nad dziećmi, ich edukację, wzory reprodukcji, partycypacji społecznej i politycznej oraz zaangażowanie obywatelskie ${ }^{2}$.

Zainteresowanie problematyka funkcjonowania rodzin rozłącznych przestrzennie wynika z aktualności problemu migracji zarobkowych, które powodują rozłąkę z rodziną. Polska cechuje się wysokim stopniem migracyjności ${ }^{3}$. Wstapienie Polski do Unii Europejskiej wiąże się z rozpoczęciem fali migracji, nazywanych poakcesyjnymi, kiedy wiele europejskich krajów dało Polakom możliwość pracy zarobkowej. Od 2004 r. zauważalny jest wzrost zainteresowania losami rodzin migrantów i burzliwa debata nad skutkami rozłąki z rodzina, która ma odzwierciedlenie m.in. w literaturze popularnej, naukowej, a szczególnie w mediach. Instytut Spraw Publicznych w raporcie Emigrować $i$ wracać - rekomendacje dla instytucji publicznych określa, że zewnętrzne migracje zarobkowe Polaków stały się „trwałym elementem polskiej rzeczywistości”.

\footnotetext{
${ }^{1}$ I. Szczygielska, Migracje zarobkowe kobiet $i$ ich wptyw na funkcjonowanie rodzin, Warszawa 2013, s. 10.

${ }^{2}$ Ibidem.

${ }^{3}$ A. Adrian, Dezintegracja rodziny jako jedna z konsekwencji migracji zarobkowych Polaków po 2004 roku, ,Przegląd Polsko-Polonijny” 2, 2011, nr 2, s. 192.

${ }^{4}$ J. Frelak et al., Emigrować $i$ wracać - rekomendacje dla instytucji publicznych. Analizy $i$ Opinie, ISP 2006, s. 2.
} 
Społeczeństwo polskie odznacza się bardzo długą historią mobilności. Polska nazywana jest krajem emigracji, co oznacza, że znacznie bardziej popularne sa wyjazdy za granicę niż imigracja cudzoziemców ${ }^{5}$.

Dotąd nieznanym problemem było pozostawianie dzieci w kraju pochodzenia przez migrantów, określane popularnie „eurosieroctwem”. Istnieją skrajne przypadki rodzin, w których oboje rodzice migrują zarobkowo poza granice kraju, a dzieci pozbawione są ich opieki. Przez badaczy i publicystów intensywnie opisywane są konsekwencje funkcjonowania rodzin rozłącznych przestrzennie. Sylwia Urbańska mówi o wybuchu paniki społecznej w związku z retradycjonalizacją ról rodzicielskich i powstaniu dyskursu eksperckiego wokół eurosieroctwa?

Dzieci migrantów zarobkowych, których wyjazd za granicę nastapił po wstapieniu Polski do Unii Europejskiej, początkowo w mediach, następnie w publikacjach popularnonaukowych i ostatecznie naukowych zaczęto określać mianem „eurosierot”, natomiast fakt pozostawienia ich bez opieki rodziców „eurosieroctwem"8. Bezrefleksyjne posługiwanie się terminem eurosieroctwo stało się źródłem rozmaitych kontrowersji ze względu na brak jednoznacznej definicji tego pojęcia oraz bogate zróżnicowanie kryteriów definicyjnych ${ }^{9}$. Brak rzetelnych, publicznie dostępnych informacji na temat funkcjonowania rodzin migracyjnych wzmacnia stereotypy i „dyskursy migracyjne" toczone w atmosferze skandalu i paniki, która znajduje wyraz w mediach, szczególnie elektronicznych ${ }^{10}$.

Poruszanie tematyki funkcjonowania rodzin migracyjnych i konsekwencji rozłąki z rodziną odbywa się kosztem dzieci wywodzących się z tych rodzin. Przegląd dostępnych w Internecie i opublikowanych w prasie artykułów dotyczacych eurosieroctwa i funkcjonowania rodzin rozłącznych przestrzennie pozwala zauważyć, że przedstawiają one młodzież głównie w świetle obciążającej cechy. Warto podkreślić, że eurosieroctwo to nadal niedokładnie zbadany problem społeczny, którego konsekwencje w dłuższej perspektywie nie zostały jeszcze poznane.

\section{SKALA ZAGRANICZNYCH MIGRACJI POLAKÓW}

Rodziny transnarodowe (migracyjne/ rozłączne przestrzennie) nie są zupełnie nową formą więzi rodzinnych powstała po akcesji, chociaż po 2004 r. obserwuje się w Polsce podwojenie liczby gospodarstw domowych, w których skład

${ }^{5}$ P. Kaczmarczyk, J. Tyrowicz, Wspótczesne migracje Polaków, Warszawa 2007, s. 4.

${ }^{6}$ S. Trusz, M. Kwiecień, Społeczne piętno eurosieroctwa, Warszawa 2012, s. 34.

${ }^{7}$ S. Urbańska, Cała Polska liczy eurosieroty: panika moralna i płeć w wykluczeniu oraz stygmatyzacja rodzin migrantów, „Kultura i Społeczeństwo” 3, 2010, s. 63-65.

8 S. Trusz, M. Kwiecień, op. cit., s. 40.

${ }^{9}$ Ibidem.

${ }^{10}$ K. Slany, M. Ślusarczyk, Migracje zagraniczne Polaków w świetle NSP 2011. Trendy i charakterystyki socjo-demograficzne. Młoda polska emigracja $w$ UE jako przedmiot badań psychologicznych, socjologicznych i kulturowych EuroEmigranci.PL, Kraków 2013, s. 20. 
wchodzą emigranci ${ }^{11}$. Już klasyczna praca Floriana Znanieckiego i Williama Thomasa poruszała tę problematykę. Praca Chłop Polski w Europie i Ameryce jest socjologiczna analizą rodzin rozłącznych przestrzennie zamieszkujących obszary wiejskie w latach dwudziestych ubiegłego wieku ${ }^{12}$.

Migracja zarobkowa społeczeństwa polskiego początek miała na przełomie XIX i XX w. w związku z przeludnieniem i niekorzystną sytuacją gospodarcza i polityczna. Natomiast rynki pracy krajów Europy Zachodniej oraz Ameryki Północnej i Południowej dawały Polakom możliwość poprawy sytuacji materialnej. Główną przyczyną migracji była wówczas chęć poprawy warunków życia czy choćby zapewnienie minimum egzystencji ${ }^{13}$. Migracje nasiliły się po II wojnie światowej. Silne ruchy migracyjne w związku z pogarszająca się sytuacją ekonomiczną kraju występowały również w latach osiemdziesiątych ${ }^{14}$. Nastroje społeczne w tamtym okresie sprzyjały mobilności Polaków.

Od 1 maja 2004 r. zmianie uległa specyfika mobilności Polaków. Coraz bardziej popularna stała się migracja legalna. Powszechne stały się wyspecjalizowane firmy rekrutujace do pracy za granica. Migracje poakcesyjne cechowały się wówczas dużą skalą migracji cyrkularnych, polegających na sezonowych wyjazdach i powrotach, oraz spadkiem popularności migracji na stałe. Dwukrotnie większa w porównaniu z danymi sprzed 2004 r. jest migracja zarobkowa do różnych europejskich krajów ${ }^{15}$. Raport Informacje o rozmiarach $i$ kierunkach emigracji $z$ Polski w latach 2004-2010 opracowany przez Główny Urząd Statystyczny (2011) wskazuje, że poakcesyjna emigracja Polaków najwyższą wartość (2 270 000) osiagnęła w 2007 r. ${ }^{16}$ Od 2008 r. zauważalna jest wśród Polaków mniejsza popularność wyjazdów zarobkowych za granicę ${ }^{17}$. W 2011 r. Narodowy Spis Powszechny wykazał, że prawie 10\% gospodarstw domowych zawierało w swym składzie emigranta, a większość stanowiły rodziny, w których nie wszyscy członkowie wyemigrowali za granicę, 91,8\% spośród nich stanowiły gospodarstwa, z których wyjechała jedna osoba ${ }^{18}$. W tym samym roku było 100000 dzieci, których jedno (lub oboje) z rodziców przebywało za granica, pozostawiając je w kraju ${ }^{19}$.

Tendencja spadkowa utrzymywała się w latach 2008-2010, natomiast aktualne dane z Głównego Urzędu Statystycznego (2016) wskazuja, że od 2015 r. zauważalny jest ponowny wzrost zasobów imigracyjnych Polaków za

\footnotetext{
${ }^{11}$ Główny Urząd Statystyczny, Informacja o rozmiarach $i$ kierunkach czasowej emigracji $z$ Polski w latach 2004-2015, Warszawa 2016, s. 2.

${ }^{12}$ F. Znaniecki, W. I. Thomas, Chtop polski w Europie i Ameryce, Warszawa 1976.

${ }^{13}$ S. Trusz, M. Kwiecień, op. cit., s. 25-26.

${ }^{14}$ P. Kaczmarczyk, Wspótczesne migracje z Polski - statystyczna ocena zjawiska, w: idem (red.), Wspótczesne migracje zagraniczne Polaków. Aspekty lokalne i regionalne, Warszawa, s. $14-15$.

${ }^{15}$ Główny Urząd Statystyczny, Gospodarstwa domowe i rodziny z osobami przebywajacymi czasowo za granica - $w$ świetle badania reprezentacyjnego przeprowadzonego $w$ ramach NSP 2011, Warszawa 2012, s. 4.

${ }^{16}$ Główny Urząd Statystyczny, Informacja o rozmiarach $i$ kierunkach emigracji z Polski $w$ latach 2004-2010, Warszawa 2011, s. 1.

${ }_{17}$ S. Trusz, M. Kwiecień, op. cit., s. 28.

${ }_{18}$ Główny Urząd Statystyczny, Gospodarstwa domowe i rodziny..., s. 1-3.

19 Ibidem, s. 6.
} 
granica ${ }^{20}$. W 2015 r. emigranci czasowi to 2397000 osób, o 77000 (czyli 3,3\%) więcej niż w 2014 ${ }^{21}$. Liczba ta przewyższa rekordową migrację w 2007 r. Raport Instytutu Publicznego z 2006 r. opisywał prognozy dotyczące emigracji z Polski ${ }^{22}$ : przewidywania mówiące o tym, że przy bezpieczeństwie zatrudnienia i wzroście wynagrodzeń w Polsce będzie można obserwować dużą skalę powrotów do kraju, nie sprawdziły się.

Prowadzenie badań dotyczących migracji i tworzenie statystyk z tym związanych jest bardzo trudnym zadaniem. Ruchy migracyjne maja bardzo zróżnicowaną charakterystykę. Wciąż brakuje danych na temat funkcjonowania rodzin rozłącznych przestrzennie i skali migracji wiążących się ze zmianą struktury gospodarstw domowych. Lukę tę wypełnić miał Narodowy Spis Powszechny z roku 2011, jednak nie opublikowano szczegółowych informacji na temat istoty tego typu emigracji ${ }^{23}$. Migracje na stałe różnią się od mobilności cyrkularnej czy wyjazdów do pracy sezonowej co do przyczyn i specyfiki przesiedleń. Bardzo zróżnicowani są sami uczestnicy ruchów migracyjnych. Badacze zauważaja, że po akcesji szacowanie staje się jeszcze trudniejsze. Już w latach dziewięćdziesiątych migracja przestała być rozpatrywana w kategoriach sukcesu. Wyjazd w celach zarobkowych z Polski zaczynał być coraz częściej traktowany jako oznaka bezradności i braku umiejętności poradzenia sobie na rynku pracy. Za główną przyczynę migracji Polaków zwykło się uznawać niekorzystną sytuację finansową i wyższe zarobki za granicą. Wśród społecznych skutków migracji zarobkowych doszukiwać się można wzrostu problemów społecznych wśród młodzieży z rodzin rozłącznych przestrzennie. Badania w Bułgarii i Mołdawii wskazuja, że wyjazdy zarobkowe rodziców związane z pozostawianiem dziecka w kraju pochodzenia mają przełożenie na spadek osiagnięć w nauce i demoralizację młodzieży ${ }^{24}$.

\section{WŁADZA RODZICIELSKA A ROZłĄKA MIGRACYJNA}

Problematyka funkcjonowania rodzin rozłącznych przestrzennie poruszana jest również w obszarze nauk prawnych w związku z niejasną sytuacją prawną związana z nieobecnością rodziców. Przysługująca obojgu rodzicom władza rodzicielska ${ }^{25}$ w sytuacji ich wyjazdu zarobkowego staje się kwestią kontrowersyjna. Do czasu pełnoletności dziecka rodzice powinni wykorzystywać zakres swojej władzy ze względu na dobro dziecka i interes społeczny. We władzy rodzicielskiej mieszczą się obowiązki oraz uprawnienia w stosunku do dziecka i jego majątku, których celem jest ochrona dobra dziecka i przygotowanie go do

${ }^{20}$ Główny Urząd Statystyczny, Informacja o rozmiarach $i$ kierunkach czasowej emigracji $z$ Polski w latach 2004-2015, Warszawa 2016, s. 2.

${ }^{21}$ Ibidem.

${ }_{22}$ J. Wiśniewski, M. Duszczyk, Emigrować i wracać. Migracje zarobkowe Polaków po 1 maja 2004, ISP, Warszawa 2006, s. 36-41.

${ }^{23}$ K. Slany, M. Ślusarczyk, op. cit., s. 3.

${ }^{24}$ World Bank, Migration and Remittances: Eastern Europe and the Soviet Union, Washington 2007 , s. $178-179$

${ }^{25}$ Art. $97 \S 1$ k.r.o. 
dorosłego, samodzielnego życia ${ }^{26}$. Obowiązkiem rodziców jest stworzenie dziecku odpowiednich warunków do osiagania samodzielności.

W sytuacji kiedy „władza rodzicielska przysługuje obojgu rodzicom, każde z nich jest obowiązane i uprawnione do jej wykonywania"27. Pomoc osób trzecich w opiece nad dzieckiem jest dopuszczalna, nawet konieczna, nie polega jednak na przekazaniu i jednoczesnym wyzbyciu się władzy rodzicielskiej. Opieka innych osób wówczas ogranicza się jedynie do spraw organizacyjnych i częściowo wychowania dziecka. Kwestia problematyczną w sytuacji rozłąi migracyjnej rodziców z dzieckiem jest brak umocowań prawnych sprawowania opieki nad pozostajacym w kraju dzieckiem przez osoby trzecie $\mathrm{e}^{28}$. Zdarza się, że rodzice, wyjeżdżając do pracy za granicę, powierzają innej osobie opiekę nad dzieckiem, ale nie powołują opiekuna w sensie prawnym, co sprawia, że opiekun tymczasowy nie podlega żadnej kontroli. W przypadku powołania opiekuna i jego niewywiązywania się z zobowiązań sąd opiekuńczy może nałożyć na niego karę grzywny ${ }^{29}$.

Szczególnie problematyczna jest kwestia braku informacji w środowisku szkolnym o przekazaniu opieki nad dzieckiem przez emigrantów zarobkowych. Nauczyciele wskazuja, że w sytuacji braku informacji o przekazaniu opieki nie mogą wywiązać się z wielu swoich obowiązków. Migracja zarobkowa rodziców i pozostawienie dziecka w kraju pochodzenia ogranicza możliwość wypełniania obowiązków związanych z posiadaniem władzy rodzicielskiej. Może być to podstawą zawieszenia ${ }^{30}$ lub w skrajnych sytuacjach pozbawienia władzy rodzicielskiej ${ }^{31}$. Sąd opiekuńczy pozbawia władzy rodzicielskiej, jeżeli ta nie może być wykonywana ze względu na trwałe przeszkody lub rodzice zaniedbują swoje obowiązki w sposób rażący. Nie jest to orzeczenie ostateczne i władza rodzicielska może być przywrócona. Po otwarciu europejskich rynków pracy na polską siłę roboczą 1299 dzieci z powodu migracji zarobkowej rodziców trafiło do domów dziecka ${ }^{32}$.

\section{RODZINA TRANSNARODOWA JAKO NOWA FORMA WIĘZI}

Nierozerwalny związek rodziny i środowiska społecznego sprawia, że zagrożenia o charakterze globalnym odciskają piętno także w płaszczyźnie życia rodzinnego. Sytuacja ekonomiczna oraz posiadanie zasobów materialnych gwarantujących dostateczny poziom jakości życia nie są bez znaczenia $\mathrm{w}$ funkcjonowaniu rodziny. Popularnym rozwiazaniem problemu bezrobocia i remedium na poprawę sytuacji materialnej jest dla polskich rodzin migracja zarobkowa. Rodziny, które mają w swym składzie migranta zarobkowego,

26 I. Szczygielska, op. cit., s. 137.

27 Cyt. za: ibidem.

28 Ibidem.

29 Art. 152 § k.r.o., art. 415, art. 471, art. 427 k.c.

${ }^{30}$ Art. 110 k.r.o.

31 Art. $111 \S 1$ k.r.o.

${ }^{32}$ M. Nowak, A. Gawęda, M. Janas-Kozik, Zjawisko eurosieroctwa a kierunki pracy terapeutycznej i leczenia psychiatrycznego - prezentacja przypadku, „Psychiatria Polska” 46(2), 2012, s. 297. 
określa się mianem rodzin czasowo niepełnych, rozłącznych przestrzennie, transnarodowych. Wioletta Danilewicz rodzinę czasowo niepełną określa mianem rozłącznej ${ }^{33}$. Natomiast rodziny rozłączne powstałe w wyniku migracji zarobkowej rodziców określa jako migracyjne. Rodzinę rozłączną przestrzennie cechuje struktura, w której jedno z rodziców wychowuje dzieci, przy ograniczonym udziale drugiego z rodziców z powodu jego czasowej nieobecności. Rodziną migracyjna natomiast jest ta, w której oboje rodzice przebywają czasowo w celach zarobkowych poza granicami kraju ${ }^{34}$.

Rodziny rozłączne przestrzennie w wyniku migracji w dyskursie medialnym zaczęły być łączone z kategorią rodzin sierocych. Warto jednak wskazać na chociażby kilka różnic między rodziną dotkniętą migracją zarobkową a rodzina sieroca. Rozłąka w rodzinie migracyjnej może nie wynikać z zupełnego rozpadu rodziny, lecz z działań mających na celu poprawę sytuacji materialnej jej członków, ma charakter czasowy, a kontakt z rodzicami uwarunkowany jest możliwościami technicznymi i może mieć cechy relacji zapośredniczonej cyfrowo, czyli odbywającej się za pośrednictwem komputera i/lub telefonu ${ }^{35}$.

Rodziny, których członkowie żyją w różnych krajach czy na różnych kontynentach, lecz łączy je wspólna kultura pochodzenia - nazywane są także rodzinami światowymi oraz globalnymi ${ }^{36}$. Mianem rodzin transnarodowych określa się takie, których członkowie zamieszkują w dwóch innych państwach ${ }^{37}$. Transnarodowa przestrzeń społeczna powstała w wyniku powszechnej cyklicznej mobilności, odnosi się do więzi między mobilnymi geograficznie osobami. Rodziny, które cechuje geograficzne rozdzielenie bliskich z powodu migracji, ale jednoczesne utrzymywanie więzi emocjonalnych oraz finansowych między emigrantem a członkami rodziny pozostałymi w kraju pochodzenia - to rodziny transnarodowe $\mathrm{e}^{38}$.

\section{STEREOTYPOWY WIZERUNEK ROZŁĄKI MIGRACYJNEJ Z RODZINA}

„Eurosieroctwo” zwykle definiuje się jako „nieobecność jednego bądź obojga rodziców w kraju oraz zaprzestanie pełnienia przez nich funkcji opiekuńczej i wychowawczej wobec dziecka"39. Warto zwrócić uwagę, że pojęcie to bywa często nadużywane, a jego ujęcia definicyjne są bardzo niespójne.

${ }^{33}$ W. Danilewicz, Sytuacja życiowa dzieci w rodzinach migracyjnych, Białystok 2006, s. 52.

34 Ibidem.

${ }_{35}$ B. Walczak, Migracje rodzicielskie, w: E. Kozdrowicz, B. Walczak (red.), Zeszyty metodyczne. Szkoła wobec mobilności zawodowej rodziców i opiekunów. Niezbędnik nauczyciela, Warszawa 2008, s. 9-10.

${ }^{36}$ U. Beck, E. Beck-Gernsheim, Miłość na odległość. Modele życia w epoce globalnej, Warszawa 2013 , s. 30 .

37 R. S. Parrenas, Children of Global Migration. Transnational Families and Gendered Woes, Stanford 2005, s. 81.

38 W. Danilewicz, Tożsamość rodzinna ,ponad granicami” w świetle koncepcji transnarodowej przestrzeni społecznej, ,Pogranicze. Studia Społeczne” 17, 2011, s. 33.

${ }^{39}$ S. Trusz, M. Kwiecień, op. cit., s. 40. 
Sławomir Trusz rozumie je jako sytuację, w której opiekunowie w wyniku migracji nie pełnią funkcji rodzicielskich wobec dziecka pozostawionego pod opieką krewnych lub wyspecjalizowanej placówki, takiej jak np. dom dziec$\mathrm{ka}^{40}$. „Eurosierota” zatem zwykło się określać dziecko pozostawione w kraju pochodzenia i pozbawione kontaktu z jednym z rodziców/rodzicami, które/ którzy nie pełnia przypisanych im ról społecznych związanych z życiem rodzinnym. Większość ujęć definicyjnych pomija aspekt psychologiczny (skutki wyjazdu opiekunów na funkcjonowanie dziecka) i skupia się na terytorialnej rozłące. Prowadzi to często do błędnych i krzywdzących ujęć eurosieroctwa jako sytuacji dotyczącej każdego dziecka, którego rodzice kiedykolwiek migrowali, bez względu na czas pobytu za granica i jakość kontaktu z dzieckiem. Pomijana jest dogłębna analiza sytuacji psychologicznej, szczególnie emocjonalnej rodziców, którzy także ponoszą konsekwencje rozłąki z członkami swojej rodziny, w tym z dzieckiem. Odpowiedzialność za trudna sytuacje przypisywana jest migrującym rodzicom, co sprawia, że ujmowani sa w kategoriach osób „krzywdzących” i pomija się fakt, że są również „ofiarami" własnych wyborów lub presji innych.

W analizach dotyczacych funkcjonowania rodzin, w których życie wpisana jest migracja rodzicielska, pojawia się kategoria sieroctwa emigracyjnego. Dla dziecka jest to sytuacja deficytu więzi emocjonalnej z jednym z (obojgiem) rodziców, która wynika z rozłąki. Dziecko odczuwa niedosyt i niezaspokojenie potrzeb, ponieważ przed emigracją zwykle rodzice, zwłaszcza z punktu widzenia dziecka, zaspokajali potrzeby emocjonalne i materialne. Nieobecność rodziców w życiu dziecka może wynikać z przyczyn trojakiego rodzaju: naturalnych, społecznych (pozostawienie/ porzucenie fizyczne dziecka) i duchowych, inaczej emocjonalnych ${ }^{41}$. Sieroctwo duchowe przejawia się wykształceniem u dziecka poczucia braku akceptacji emocjonalnej w rodzinie, braku zrozumienia przez rodziców, poczucia osamotnienia i braku zainteresowania ze strony rodziców ${ }^{42}$.

Powszechne posługiwanie się terminami „eurosieroctwo” i ,eurosierota” nie skutkuje jednak opracowaniem wyraźnych ujęć definicyjnych. Wśród autorów można zauważyć dwa rodzaje kryteriów definicyjnych. Pierwsze uznaje za eurosierotę każde dziecko pozbawione kontaktu z migrującym jednym (obojgiem) z rodziców. Drugie kładzie nacisk na znaczenie psychospołecznych konsekwencji rozłąki z opiekunami. Trudno jednak jednoznacznie ustalić negatywne konsekwencje dla rozwoju dziecka, które wynikałyby bezpośrednio z ograniczonego kontaktu z rodzicami. Brakuje dogłębnych i systematycznych badań nad psychospołecznym funkcjonowaniem członków rodzin migracyjnych ${ }^{43}$. Natomiast media i dyskurs naukowy przekazuja często informacje na temat eurosieroctwa nasycone uogólnieniami i wyolbrzymiają prob-

\footnotetext{
${ }^{40}$ Materiał nieopublikowany. Cyt. za: S. Trusz, M. Kwiecień, op. cit., s. 40.

${ }^{41}$ M. Sas-Tomczyk, Samotne dzieciństwo w rodzinie, w: J. Grotkowska-Leder (red.), Więzi społeczne. Sieci społeczne. W perspektywie procesów inkluzji i wykluczenia społecznego, Łódź 2014, s. $71-83$.

42 Ibidem.

${ }^{43}$ S. Trusz, M. Kwiecień, op. cit., s. 44-46.
} 
lemy, co skutkuje stygmatyzowaniem dzieci i młodzieży pochodzących z rodzin rozłącznych przestrzennie oraz tworzeniem ich skrajnie negatywnego, wręcz patologicznego wizerunku ${ }^{44}$.

Termin eurosieroctwo analizowany był w świetle teorii determinizmu językowego, który zakłada, że społeczne nazewnictwo nie jest przypadkowe, a struktura języka jest odzwierciedleniem percepcji otaczającego ludzi świa$\mathrm{ta}^{45}$. Użycie określonych kategorii językowych może wpływać na postrzeganie, interpretację, ocenę, zapamiętywanie i wydobywanie z pamięci określonych informacji. Nawiazujac do hipotezy Saphira-Whorfa, Gordon B. Moskowitz podkreśla, że język wpływa nie tylko na to, jak ludzie się komunikuja, ale i na ich myśli ${ }^{46}$. Posługiwanie się etykieta „eurosierota” uruchamia serię skojarzeń zwiazanych z byciem sierota i swoisty afekt. Skojarzenia te mogą uruchamiać obrazy dzieci zaniedbanych, smutnych, bezsilnych, pozbawionych nadziei. Przyjmując założenie o determinowaniu ludzkich zachowań przez procesy poznawcze, można uznać, że posługiwanie się stygmatyzujacym terminem eurosieroctwo będzie wpływać na zachowania ludzi i sposób interpretowania postępowania osób z rodzin rozłącznych przestrzennie.

Badania prowadzone przez Sławomira Trusza i Magdalenę Kwiecień ukazały przełożenie stereotypu eurosieroty na przewidywana karierę edukacyjna ucznia ${ }^{47}$. Wyniki przytoczonych badań sugerują wpływ etykiety eurosieroty na oczekiwania nauczycieli wobec uczniów z rodzin migracyjnych.

Dziecko przedstawiane jako pozbawiane opieki ze strony pracujących poza granicami kraju rodziców [...] było oceniane jako mniej zadbane, tj. gorzej odżywione i gorzej ubrane, niż to samo dziecko oceniane przez badanych, którym nie dostarczano specyficznej informacji o jego sytuacji rodzinnej. [...] Dane na temat euroemigracji zarobkowej rodzica/rodziców dziecka współwystępowały z mniej przychylnymi przewidywaniami na temat jego kompetencji intelektualnych oraz zaradności ${ }^{48}$.

Określenie eurosieroctwo składa się z dwóch członów: „sieroctwo”, które podkreśla dramat dziecka, oraz przedrostka „euro”49 (jest łatwy do zapamiętania i chwytliwy, akcentuje aktualność wyrażenia i związek ze wstapieniem Polski do Unii Europejskiej). Pojęcie „eurosieroctwo” jest neologizmem, który z jednej strony powstał w wyniku zainteresowania problematyką dzieci pozostających w kraju bez opieki rodziców przebywających za granica, z drugiej - idealnie wpisuje się w ramy medialnego skandalu. Nazywanie problemu pozostawiania dzieci bez opieki rodziców - migrantów terminem eurosieroctwo zostało określone przez polskie Ministerstwo Edukacji Narodowej jako niefortunne i stygmatyzujące dziec-

${ }^{44}$ B. Walczak, Dziecko, rodzina i szkoła, wobec migracji rodzicielskich: 10 lat po akcesji do Unii Europejskiej. Realizowane na zlecenie Rzecznika Praw Dziecka, Warszawa 2014, s. 12.

45 S. Trusz, M. Kwiecień, op. cit., s. 52-53.

${ }^{46}$ Ibidem, s. 53.

${ }^{47}$ Ibidem, s. 181-182.

48 Ibidem.

${ }^{49}$ B. Trębicka-Postrzygacz, A. Roguska, Eurosieroctwo w Polsce, Брестский государственный университет имени АС Пушкина, 2016, s. 139, https://repozytorium.uph.edu.pl/bitstream/handle/11331/1045/Trebicka-Postrzygacz.B._Roguska.A._Eurosieroctwo_w_Polsce.pdf?sequence=1 [dostęp: 16.03.2017]. 
$\mathrm{ko}^{50}$. Ze względu na jego popularność i - jak określają to Beata Trębicka-Postrzygacz i Agnieszka Roguska - „nośność medialną” trudno jest je obecnie wyeliminować ${ }^{51}$. Trusz i Kwiecińska, analizując dane dotyczące funkcjonowania młodzieży z rodzin rozłącznych przestrzennie w różnych środowiskach, od szkolnego po rodzinne, doszli do wniosku, że sytuacja eurosieroty w grupie rówieśniczej jest zdecydowanie trudniejsza niż młodzieży, której rodzice nie migruja zarobkowo $^{52}$.

\section{STYGMAT EUROSIEROCTWA}

Doniesienia prasowe i telewizyjne reportaże traktujące o pozostawianiu dzieci w kraju pochodzenia i migracji zarobkowej rodziców zwykle ukazują eurosieroty jako zaniedbane, porzucone. Sprawiaja, że osoby te zaczynają być postrzegane głównie w świetle obciążającej cechy, jaka jest pozostawienie przez rodziców. Eurosieroctwo zatem może być specyficznym atrybutem podlegającym społecznej ocenie, dyskredytującym człowieka i sytuującym go na peryferiach życia społecznego. Eurosieroctwo może stać się grupowym stygmatem w środowisku szkolnym, rówieśniczym lub indywidualną skazą. Wartość osób pochodzących z rodzin rozłącznych przestrzennie jest obniżana ze względu na posiadanie cech przypisywanych wszystkim eurosierotom. Eurosieroctwo może być łączone z agresja, skłonnością do korzystania z używek, niską motywacją do nauki i brakiem osiagnięć szkolnych ${ }^{53}$.

Wyróżnia się trzy rodzaje piętna: pierwsze odnosi się do deformacji fizycznych, drugie - do cech określanych mianem ,,wad charakteru”, trzecie - grupowe ${ }^{54}$. Piętno grupowe może wynikać z rasy, narodowości czy wyznania. Zatem eurosieroctwo oraz bycie członkiem rodziny transnarodowej może wiązać się z ostatnim typem piętna, które nakłada skazę na wszystkich członków rodziny migranta. Krewnych członków rodziny transnarodowej określić można mianem osób zorientowanych, czyli powiązanych z nosicielami piętna ${ }^{55}$. Społeczność zorientowanych i piętnowanych traktuje jak jedność. Wszystkie rodzaje piętna sprawiaja, że jednostka mogąca być akceptowaną w codziennych interakcjach społecznych staje się nosicielem drażniącej otoczenie cechy. Okoliczność ta powoduje, że cechy jednostki i jej zachowania, które mogłyby na odbiorcy wywrzeć pozytywne wrażenie, traca na znaczeniu. Osoba obarczona piętnem odbierana jest przez środowisko społeczne w określony sposób, ponieważ - jak zaznacza Erving Goffman - „osobę obciąża piętno, zasadniczo

50 Ibidem, s. 140.

51 Ibidem.

52 S. Trusz, R. Kwiecińska, Edukacyjne i społeczno-emocjonalne konsekwencje zjawiska eurosieroctwa, ,Kultura i Edukacja” 2016, nr 1(87), s.120.

53 S. Trusz, M. Kwiecień, op. cit., s. 68.

54 E. Goffman, Piętno. Rozważania o zranionej tożsamości, tłum. A. Dzierżyńska, J. Tokarska-Bakir, Gdańsk 2005, s. 33-34.

${ }^{55}$ Ibidem, s. 64. 
modyfikujace nasze antycypacje w stosunku do niej" ${ }^{56}$. Normalsi, czyli nieodbiegajacy od wspomnianych pierwotnych antycypacji, tworzą własne ideologie piętna. Na swój sposób starają się tłumaczyć niższość piętnowanych i kieruja wobec nich praktyki dyskryminujące. Codzienne interakcje przesiąknięte sa negatywnymi określeniami, jak sieroty, eurosieroty. Noszenie skazy eurosieroty czy euroemigranta i reakcję normalsów na ową skazę można postrzegać jako karę za wcześniejsze czyny. Fakt rozłąki z rodziną można interpretować jako konsekwencje braku umiejętności odnalezienia się na polskim rynku pracy, niechęcią wobec dokształcania, brakiem wykształcenia lub lenistwem. Bycie eurosierotą może być postrzegane jako kara poniesiona za pochodzenie społeczne, bycie „trudnym dzieckiem”.

Człowiek ze skazą oczekuje od otoczenia szacunku, który należy mu się ze względu na społeczną tożsamość. Jednakże otoczenie normalsów odmawia mu zarówno szacunku, uznania, jak i samego człowieczeństwa. Piętnowany zaczyna skupiać się na wszystkich swoich cechach, które mogłyby stanowić rodzaj uzasadnienia tej odmowy. Nawet cechy, które uważał wcześniej za oczywiste, zaczyna rozważać. W sytuacji konfrontacji normalsów i piętnowanych jednostka ze skazą czuje wyjątkową niepewność. Eurosierota nie wie, czego się spodziewać, nie może ustalić, w jaki sposób przyjmą i zareagują na niego normalsi. Piętnowanego można określić jako żyjącego w stałym napięciu, pilnującego tego, jakie wrażenie wywiera na innych. On zdaje sobie sprawę, że jego zachowania nie podlegają zwyczajnemu schematowi interpretacji. Nawet jednorazowe niepowodzenie może być uznane za wyraz jego odmienności.

Piętno to swoiste narzędzie, za pomoca którego utrzymuje się i tworzy hierarchie społeczne. Kiedy piętnowanego informuje się, że mimo wszystko jest człowiekiem jak każda inna jednostka, jednocześnie przekazuje się mu wiadomość o tym, że nie warto ukrywać piętna. Piętnowany otrzymuje sygnał, że jest taki jak inni ludzie, ale zarazem nie jest tożsamy z innymi osobami, które nie posiadają skazy ${ }^{57}$. Osoby ze skazą odznaczają się podobnym bagażem doświadczeń w związku z nauką własnego położenia. Podczas specyficznego procesu socjalizacji jednostki dowiadują się, na czym polega posiadanie skazy, noszenie określonego piętna ${ }^{58}$. W pierwszej fazie jednostka internalizuje stanowisko normalsów na ten temat. Natomiast w drugiej fazie uczy się, że posiada dane piętno i musi zmierzyć się z konsekwencjami skazy. Przebieg obu faz wyznaczają cztery wzorce wpływające na dalszy rozwój jednostki. Pierwszy wzorzec wiąże się z wrodzonym piętnem. Osoba w procesie socjalizacji wprowadzana jest w swoją niekorzystną sytuację, poznaje panujące standardy, którym nigdy nie będzie mogła sprostać. Dotyczy to dziecka rodzacego się w rodzinie transnarodowej, któremu od dnia narodzin przypisuje się skazę „porzucenia” przez rodzica. Drugi dotyczy osób z wrodzonym piętnem, których rodzina dołożyła szczególnych starań, aby je ochronić. W przypadku dziecka wychowującego się w rodzinie transnarodowej jego bliscy mogą chronić je przed poniżajacymi definicjami eurosieroctwa. Szczególnym momentem w tym procesie

\footnotetext{
56 Ibidem, s. 35.

57 Ibidem, s. 168 .

58 Ibidem, s. 66-70.
} 
jest pójście do szkoły. Rodzina nie może dłużej trzymać dziecka pod kloszem. Ograniczona jest również kontrola dotycząca tego, co dziecko samo przekazuje „obcym”. Jest to wyjątkowo trudny etap dla członków rodziny, a szczególnie rodziców, gdyż obawiają się demaskacji sfer prywatnego funkcjonowania. Trzeci wzorzec socjalizacji dotyczy osób, które nabywają piętno w późniejszym okresie swojego życia lub w późniejszym momencie dowiadują się, że zawsze przez swoją skazę były dyskredytowane. W ostatni wzorzec wpisuja się osoby socjalizowane w nowym środowisku, które muszą odnaleźć się i ustosunkować do panującego w obecnym otoczeniu sposobu życia. Bez względu na typ wzorca socjalizacji faza, w której jednostka dowiaduje się o posiadanym piętnie, jest szczególnie wartościowa poznawczo. W tej fazie dochodzi do redefinicji kontaktów z innymi osobami noszącymi to samo piętno. Może okazać się, że nawet chwilowy kontakt sprawi, że jednostka zauważy, że istnieja podobni do niej ludzie, ludzie tacy jak ona.

Analiza artykułów, które wskazuje przeglądarka internetowa po wpisaniu hasła „eurosieroctwo”, pozwala wyróżnić powtarzające się kwestie poruszane przez autorów w kontekście problemu eurosieroctwa i migracji Polaków. Publikacje te generalizuja obraz eurosierot jako młodzieży niestroniącej od środków psychoaktywnych, skłonnej do agresji i przejawiajacej niskie osiagnięcia edukacyjne. Natomiast obszary o wysokiej migracyjności nazywane sa „niechlubnymi rejonami Polski”. W wypowiedziach osób z otoczenia eurosierot pojawia się wątek niechcianych ciąż, których powodem jest brak kontroli ze strony migrujących rodziców. Szczególnie podkreślana jest skala zjawiska, natomiast opis specyfiki funkcjonowania rodzin migracyjnych ogranicza się do krzywdzacych ocen i ujednolicania obrazu wszystkich dzieci migrantów. Popularne wobec tego jest posługiwanie się stereotypem eurosieroty, czyli uproszczonym obrazem myślowym ${ }^{59}$.

Wizerunek młodzieży z rodzin rozłącznych przestrzennie przedstawiony w mediach jest zgeneralizowany. Migrujący rodzice traktowani sa jako wyrodni opiekunowie, a dzieci jako porzucone i zaniedbane. Uwzględniając perspektywę piętnującego, praktyki piętnowania wiążą się z niechęcią do eurosieroctwa i sprowadzeniem charakterystyki dzieci migrantów do karykaturalnego stereotypu $^{60}$. Eurosieroctwo opisywane w artykułach w kontekście skandalu wychowawczego zaczyna naznaczać młodzież z rodzin rozłącznych przestrzennie w taki sposób, że ta staje się dla odbiorcy mniej warta niż młodzież wychowująca się w rodzinach, w których rodzice nie migrują zarobkowo.

Problem piętnowania nie jest zjawiskiem jednowymiarowym i łatwym do opisu. Badania dotyczące ważności norm społecznych w uprzedzeniach wskazują że nieprzychylności jednej grupy wobec drugiej nie można wyjaśnić indywidualnymi cechami osobowości. Przewidzieć je można jedynie na podstawie analizy norm kulturowych i indywidualnej uległości wobec norm. Normy

${ }^{59}$ A. Bullock, O. Stallybrass, The Fontana Dictionary of Modern Thought, London 1983, s. 601.

${ }^{60}$ J. F. Dovidio, B. Major, J. Crocker, Piętno: wprowadzenie i zarys ogólny, tłum. M. Szuster, w: T. F. Heatherton et al. (red.), Społeczna psychologia piętna, tłum. J. Radzicki, M. Szuster, T. Szustrowa, Warszawa 2008, s. 23-24. 
społeczne przenikają wszystkie warstwy społeczeństwa. Piętnowanie nie jest zatem bezpośrednio kwestią indywidualna, lecz związane jest z całym kontekstem społecznym. Napiętnowany nie tylko podlega bezpośrednim praktykom ze strony jednostek, ale również całego społeczeństwa, które podtrzymuje istniejący stan. Piętnujący zatem odtwarza zachowania już istniejące, uznawane za właściwe, uwzględniając kontekst kontroli społecznej, gdyż zgodne z panującymi w społeczeństwie normami ${ }^{61}$. Kontrola społeczna odnosi się do procesów, przez które jednostki są nakłaniane i zmuszane do konformistycznego postępowania, zgodnie ze zwyczajami i wartościami panującymi w grupie $^{62}$. Oddziałuje ona na jednostki przez normy, wzory i wartości, które wobec „,swoich” pełnią funkcje regulujące, natomiast wobec ,obcych” przybierają postać ostracyzmu i naznaczania.

Przywołując kategorie piętna i stygmatyzacji, nie należy pomijać teorii labelingu ${ }^{63}$, inaczej: teorii naznaczania społecznego. Fundamentalnym założeniem teorii labelingu jest twierdzenie mówiące o tym, że aby wyjaśniać zachowania uznawane za zaburzone $\mathrm{w}$ danym społeczeństwie, należy przeanalizować społeczne oczekiwania w stosunku do jednostek uznawanych za dewiacyjne. W przypadku nierespektowania oczekiwań społeczeństwa, bycia odmieńcem, jednostka doświadcza negatywnej reakcji społecznej, która polega na karaniu „obcych”64. Karaniem moga być praktyki piętnujące, kategoryzowanie, stosowanie etykiet. Zdarza się, że do etykietowania dochodzi tylko dlatego, że jednostka jest identyfikowana z rodzina patologiczną i wówczas staje się „bezradną ofiarą systemu naznaczenia”65. Teoria labelingu odnosi się do tych sytuacji, w których jednostka utożsamia się z przypisana jej odmiennościa ${ }^{66}$. „Obcy”, w tym przypadku młodzież z rodzin rozłącznych przestrzennie, zaczyna patrzeć na siebie oczami reszty społeczeństwa, któremu udało się wykreować jej negatywny obraz.

Rzeczywistość społeczna oznacza istnienie takich zjawisk, które nie są zależne od woli jednostki, jak wskazują Peter L. Berger i Thomas Luckmann: „,nie możemy pozbyć się pewnych własności na życzenie” ${ }^{7}$. Świat społeczny skonstruowany jest w taki sposób, że źródłem instytucjonalnego porządku sa praktyki określane mianem typizacji ${ }^{68}$. Typizacje zostały określone jako naturalna potrzeba kategoryzowania ludzi. Typizowane sa poza samymi działaniami jednostek ich formy. Działania ludzi i nadawany im sens można rozpatrywać w oderwaniu od indywidualnych form ich realizacji. Sposób działania

${ }^{61}$ T. E. Pettigrew, Regional differences in anti-Negro prejudice, ,,Journal of Abnormal and Social Psychology" 59, 1959, s. 28-36.

${ }^{62}$ A. Siemaszko, Granice tolerancji. O teoriach zachowań dewiacyjnych, Warszawa 1993, s. 203-205.

${ }^{63}$ Labeling oznacza dosłownie „etykietowanie” (,znakowanie, szufladkowanie”).

${ }^{64}$ E. Lemert, Social Pathology: A Systematic Approach to the Theory of Sociopath Behavior, New York 1951, s. 77.

${ }_{65}^{65}$ M. Oliwa-Ciesielska, Piętno nieprzypisania. Studium o wyizolowaniu spotecznym bezdomnych, Poznań 2006, s. 165.

${ }^{66}$ Ibidem, s. 163.

${ }^{67}$ P. L. Berger, T. Luckmann, Społeczne tworzenie rzeczywistości, tłum. J. Niżnik, Warszawa 1983, s. 23.

${ }^{68}$ Ibidem, s. 121-122. 
wszystkich tzw. eurosierot jest typizowany społecznie i kategoryzowany jako typowy dla eurosieroctwa, bez względu na podmiotowy charakter działania tych osób. Odgrywanie ról społecznych sprawia, że jednostki uczestnicza w rzeczywistości społecznej, mimo istnienia niesprawiedliwych praktyk dyskryminujących, internalizacja roli prowadzi do tego, że dla jednostek świat ten staje się, jak to określają Berger i Luckmann, ,,subiektywnie rzeczywisty”69.

Naznaczająca reakcja społeczna może powodować nieprzystosowanie osób określanych mianem eurosierot. Jednostka może wejść w rolę dewianta i potwierdzić tym samym społeczne oczekiwania. Chwila decydująca o wejściu $\mathrm{w}$ rolę dewianta jest publiczne naznaczenie, przypisanie etykiety. Nieprzystosowanie nie jest immanentną cechą wszystkich dzieci wychowujących się bez rodziców/ jednego z rodziców, lecz zjawiskiem nazwanym tak przez ludzi $\mathrm{z}$ ich otoczenia. Publiczne formułowanie generalizujących i krzywdzących ocen postępowania młodzieży z rodzin rozłącznych przestrzennie może skutkować ich rzeczywistym wejściem w rolę dewianta i kształtowaniem własnego negatywnego obrazu siebie.

\section{ZAKOŃCZENIE}

Młodzież z rodzin rozłącznych przestrzennie pozbawiona jest kontroli i nadzoru przebywającego w kraju emigracji jednego z rodziców, może czuć się zwolniona z wykonywania obowiązków dotychczasowych. Jednocześnie obarczana jest nowymi obowiązkami i spoczywa na niej odpowiedzialność za podejmowanie, często bardzo trudnych, decyzji ${ }^{70}$. W medialnych przekazach ignoruje się doniesienia o codziennym funkcjonowaniu młodzieży z rodzin rozłącznych przestrzennie, które - co szczególnie warto podkreślić - charakteryzuje twórcze radzenie sobie przez młodzież z przeciwnościami, konieczność dopasowania się do nowego sposobu życia, rozumienie własnego spektrum aktywności oraz integrowanie własnej historii życia.

Za wytworzenie stygmatów zawsze odpowiada „społeczna widownia”. Gdy społeczne wyobrażenie na temat eurosieroctwa nie jest zgodne z panującymi normami, reakcją na odmienność jest redukcja zróżnicowanego, wielowymiarowego obrazu jednostki do kilku upokarzających epitetów. Problem eurosieroctwa jest szczególny ze względu na to, że eurosierota nosi stygmat, mimo że swoim zachowaniem nie łamie panujących norm ani nie posiada dyskredytujaccej cechy. W zasadzie eurosierota naznaczona jest dlatego, że jedno z jej rodziców uczyniło coś, co społecznie postrzegane jest w kategoriach dewiacji. Dyskredytujące określenie „ofiara losu” posiada w tym przypadku uzasadnioną konotację ${ }^{71}$.

69 Ibidem.

${ }^{70}$ D. Becker-Pestka, Rodzina w obliczu migracji zarobkowej, „Colloquium Wydziału Nauk Humanistycznych i Społecznych. Kwartalnik” 2012, nr 1, s. 16.

${ }^{71}$ M. Oliwa-Ciesielska, op. cit., s. 166. 
Zapewne ograniczenie używania stygmatyzujących etykiet $\mathrm{w}$ doniesieniach medialnych oraz przedstawianie historii życia młodych osób wychowujących się $\mathrm{w}$ rodzinach migracyjnych pomogłyby ukazać ich codzienne doświadczenia oraz byłyby efektywne i wartościowe poznawczo w analizie problemu eurosieroctwa oraz mniej piętnujace. Ważne w badaniu i reagowaniu na problem eurosieroctwa jest współdziałanie sektora edukacji, pomocy społecznej i nauki, na co zawracaja uwage m.in. Bartłomiej Walczak i Ewa Kozdrowicz. Pomocne byłoby kompleksowe działanie, poprzedzone diagnoza sytuacji i określeniem właściwych sposobów interwencji. Rodzina o strukturze rozłącznej wymaga lepszego poznania, aby móc projektować adekwatną ofertę pomocy, na przykład w zakresie prawa, wsparcia psychologicznego czy terapii. Pomocne w ograniczeniu piętnujących praktyk mogłoby okazać się szkolenie kadry nauczycielskiej.

Badania dotyczace funkcjonowania rodzin rozłącznych przestrzennie wskazują na konieczność zorganizowania doradztwa i wsparcia w związu $\mathrm{z}$ ich zmiana $\mathrm{w}$ sposobie życia. Wiedza na temat negatywnych konsekwencji migracji może pomóc w podjęciu działań mających na celu zabezpieczenie przed zagrożeniami związanymi z rozłąka. Szczególnie należałoby rozważyć wszystkie możliwe konsekwencje rozłąki z bliskimi, które obszernie ilustruje literatura przedmiotu.

mgr Natasza Doiczman

Uniwersytet im. Adama Mickiewicza w Poznaniu

natasza.doiczman@amu.edu.pl

THE IMAGE OF A TRANSNATIONAL FAMILY IN THE CONTEXT

OF THE CONCEPT OF STIGMA AND STIGMATISATION

Summary

The purpose of this paper is to define the stereotypical image of a transnational family in the context of the concept of stigma and stigmatisation. The analysis is based on the assumptions of the interactive theory, with particular reference to Erving Goffman's concept of stigma. The introductory part of the paper, dealing with the underlying social consequences of the functioning of transnational families, has been based on the characteristics of Polish post-EU accession migrations, with particular focus on the current issues. Attention has been paid to the legal problem connected with migrations of parents and resulting from these migrations failure of migrant parents to exercise their parental responsibility. The article also presents various views on the definition of a transnational family, being an alternative to the socio-cultural construct of a full family. The key theme in the discussion presented in the paper is the focus on the role of 'social audience' in the creation of the stigmatisation of a 'euro-orphan'. 


\section{INFORMACJE DLA AUTORÓW}

1. Objętość nadsyłanych tekstów nie może przekraczać 1 ark. wyd. (36-40 tys. znaków wraz ze spacjami i przypisami) w wypadku artykułu bądź maksymalnie 10 tys. znaków w wypadku recenzji.

2. Teksty należy przesyłać $\mathrm{w}$ formie wydruku oraz $\mathrm{w}$ wersji elektronicznej wraz z nośnikiem lub na adres poczty elektronicznej Redakcji (rpeis@amu.edu.pl).

3. Wszelkie tabele, wykresy lub ryciny będące częścią tekstu należy również przesyłać w formie edytowalnego zapisu elektronicznego. Minimalna grubość linii rysunku powinna wynosić 0,4 pkt, a rysunki należy sporządzić $\mathrm{w}$ wersji czarno-białej, w formacie nie większym niż format kolumny $(126 \times 180 \mathrm{~mm})$.

4. Do artykułu należy dołączyć krótkie streszczenia (abstrakty) w języku polskim i angielskim (ok. 1,5 tys. znaków), słowa kluczowe, a także zestawienie cytowanej literatury.

5. Do przesłanego tekstu należy dołączyć dane o autorze, adres do korespondencji, numery telefonów i adres poczty elektronicznej. W wypadku pracowników naukowych prosimy także o podanie nazwy i adresu uczelni macierzystej.

6. Do przesłanej propozycji publikacji należy dołączyć oświadczenie, że przedłożony tekst został nadesłany wyłącznie do Redakcji „Ruchu Prawniczego, Ekonomicznego i Socjologicznego".

7. Termin wykonania korekty autorskiej wynosi maksymalnie 1 tydzień. Po upływie tego terminu tekst kierujemy do publikacji wyłącznie z korekta redakcyjna.

8. Publikacje w kwartalniku RPEiS nie sa płatne.

9. Redakcja nie zwraca materiałów niezamówionych.

10. Decyzja Autora o publikacji w RPEiS oznacza zgodę na zarchiwizowanie tekstu w wersji elektronicznej w ogólnodostępnym Repozytorium UAM (http://repozytorium.amu.edu.pl) oraz The Central European Journal of Social Sciences and Humanities (http://cejsh.icm.edu.pl), a także w profesjonalnej bazie danych: System Informacji Prawnej Legalis.

Szczegółowe zalecenia edytorskie i techniczne dla Autorów znaleźć można na www.rpeis.pl 
